\title{
A COMMUNITY OF SPOKEN WORDS: FORMS AND PRACTICES OF THE CONVERSATION AT VIAT⿱A ROMÂNEASCĂ CENACLE
}

\author{
Maricica MUNTEANU \\ The "A. Philippide" Institute of Romanian Philology \\ e-mail: mari.munteanu@ymail.com
}

\begin{abstract}
The present article analyses the conversation of the cenacle Viața românească by exploring three directions of research. In the first place, the study concentrates on the conversation as a phenomenon of loss, focussing on the voice of the writers and oral speech as signs of extreme fragility. On the one hand, the reflection on the absence of the spoken word articulates an imaginary of evanescence that functions as a collective representation of the community. On the other hand, it reconsiders the relation between the oral and the written word by favouring the conversation against the literary work. In the second place, the article investigates the forms of the conversation specific to the cenacle as they appear in the memoirs of some members. Representing the cenacle as a democratic society where each member has equal rights, the memoirs of the cenacle depict, at the same time, some regulations that limit the speech such as the anti-rhetoric, the delicacy, and the admiration. Finally, the last issue to be approached is the content of the conversation. On the one hand, the cenacle represents itself as an elevated group that discusses the issues of literature, investing in the "profitable" conversation (Glinoer, Laisney) at the expense of the agreeable interaction. On the other hand, the cenacle values the forms of entertainment as a way of detachment from writing, the study focussing, in the last part, on the functions of laughter inside the literary community.
\end{abstract}

Keywords: conversation; cenacle; phenomena of loss; laughter; Viața românească;

From the start, the conversation of the writers is a difficult subject to be approached as this practice, analysed in the present article rather in its performative than discursive dimension, is an unfixed domain, subject to temporal erosion. Due to its duality, oral and written at the same time ${ }^{1}$, the

\footnotetext{
${ }^{1}$ Vincent Laisney shows that the conversation is a hybrid material as it is difficult to be classified being at the same time oral as it is linked to speech and written as it is also transferred on the paper. Furthermore, the authorship of the conversation is a problematic fact as it is disputed between the speaker and the one who writes it down (Laisney, 2003, available on https://www.cairn.info/revue-d-histoire-litteraire-de-la-france-2003-3-page643.htm\#, seen on the $3^{\text {rd }}$ of February 2020).
} 
conversation is showing a tangential interest for the Romanian literary history, a positivist and document-centred discipline, being classified as an incidental and anecdotal practice of the literary mediums and not so much as a literary phenomenon that is capable to point out some interesting facts about literature. However, the recent literary history ${ }^{2}$ aims to develop new instruments of investigation, opening towards cultural studies, anthropology, or sociology, and shifting its purpose from the restitution of the documents to the reconsideration of the absent places that focus on the dynamics of literature and the interactions between the literary and the social and cultural phenomena. The traditional approach of literature as an accumulation of canonized literary works and canonized authors is being re-evaluated by the investigation of literature as a social experience, in which case the creativity itself becomes a matter of plurality and collectiveness. In this context, the literary studies reconsider the "spoken word" not so much as an anecdotal charge or "atmosphere" of the great works but as essential for the creative process $^{3}$. The rising interest for the literary sociability addresses the issue of conversation in its various aspects, but the focus of the present paper is on the conversation of the cenacle that presents several particularities. Anthony Glinoer and Vincent Laisney (2013) assert that the conversation of the cenacle derives as an opposition to the institutionalized conversation of the French salons ${ }^{4}$, carrying the image of a democratic society, unbound to rhetorical rules and free of hierarchies. This reluctance to the salons brings an important transformation in the imagery of the conversation: la causerie for the mere pleasure of the word is replaced by the new form of literary interaction in a "profitable" conversation, in this case, for the profit of literature. Nevertheless, as Glinoer and Laisney show, this image of the utilitarian word is completed with (and competed by) the practice of the cenacle, that is not strange from the agreeable conversation. Viața românească cenacle ${ }^{5}$ is a good example for this oscillation between the high

\footnotetext{
${ }^{2}$ See, for example, José-Lui Diaz, Quelle histoire littéraire?, in Revue d'histoire littéraire de la France, 2003, available on https://www.cairn.info/revue-d-histoire-litteraire-de-la-france2003-3-page-515.htm, seen on the $3^{\text {rd }}$ of February 2020.

${ }^{3}$ See the thematic inquiry entitled Paroles vives (Blaise, Triaire, Vaillant, 2009: https://books.openedition.org/pulm/829?format=toc).

${ }^{4}$ Marc Fumaroli considers that the conversation is an institution in France along with the Academy and the genius of language (Fumaroli, 1994).

${ }^{5}$ When speaking about Viața românească cenacle I refer to the group of writers organized around the magazine of the same name that activated in Iași between 1906 and 1930. Even though the magazine continues to appear after 1930 at Bucharest, I take into consideration only this time frame as the forms of sociability disappear once the magazine is relocated. One of the most read publications of this particular period, Viața românsească presents an alternative to the modernism and the theory of synchronicity proposed by E. Lovinescu by arguing the importance of traditions and national specificity in the modernization of literature.
} 
and fruitful conversation and the small talk. In the Romanian cultural space, the study of the literary forms of sociability is quite deficient, one of the notable studies being Ligia Tudurachi's pioneer work Grup sburător. Scrisul şi trăitul împreună în cenaclul lui E. Lovinescu (2019). The researcher reinterprets the conversation as literature (the domain where the writing has the capital importance) because the writers of "Sburătorul" perceive the spoken word as their personal property, subject to the "theft" of the companions. The choice for Viața românească cenacle has a twofold argument. On the one hand, the Romanian literary studies focus either on the ideology of Viata românească group in such studies as Poporanismul/ The Poporanism (1972) by Z. Ornea that analyses the concept of "poporanism" in relationship to sociological, political, and cultural aspects, and Liviu Leonte's Continuitate și înnoire ("Viața româneacă" în perioada interbelică)/ Continuity and innovation ("Viața româneacă" in the interwar period) (1998) that evaluates the dynamics of the concept in the interwar period. The present article is centred on the social interactions, and the intimate practices, bringing a new perspective on the mechanism and functionality of the literary groups. On the other hand, the conversation has a central place in the constitution of the collective imagery, even superseding the reading ${ }^{6}$, a central practice in other cenacles. ${ }^{7}$

In the following analysis on Viața românească cenacle, I plan on delimiting several areas of issues. In the first place, the investigation on conversation opens up the discussion about the phenomena of loss such as the voice, the tonalities, the gestures, and the spoken words of the writer, aspects that are registered in the memoirs of the cenacle as perishable and irrecoverable. In the second place, another aspect to be addressed is the relation between the cenacle and the spoken word, namely the ideas, the representations, and the imagery built up around the conversation. In this respect, does the "democratic" image provided by the memoirs coincide with the practice; is the cenacle really free of hierarchies? Finally, the focus stays on the content of the conversation: is it the high-end conversation, and the literary affairs, or the anecdotes that animate the cenacle?

Although the memoirs of Viața românească cenacle contain information on the issue of conversation, it is difficult to resume the actual discussions taken place in the space of the editorial office. In my opinion,

\footnotetext{
${ }^{6}$ Public reading is an incidental activity at Viața românească; its purpose is to please the audience and not to evaluate the writings, in which case just few writers read their works (Mihail Sadoveanu, G. Topîrceanu, Constantin Stere, Ioan Al. Brătescu-Voinești). This "silence" may be explained in relation with Ibrăileanu's philosophy on reading that employs such terms as "pleasure" or "mystery" of literature.

${ }^{7}$ For comparison, see the reading practice at "Sburătorul" as analysed by Ligia Tudurachi (2019: 93-114).
} 
there are two explanations for this: on the one hand, the temporal gap between the speech and the registration on the paper $^{8}$ leads to the selection of facts due to the memory process and transforms them into images of the past. On the other hand, the conversation itself is a fragile phenomenon as it is, first of all, oral (also implying non-verbal and para-verbal elements) and temporary. However, the memoirs also carry an advantage: they reflect on this phenomenon of loss and on the impossibility of recovering, this registered absence functioning as collective representation. The writers of memoirs are sensitive to all sorts of discursive elements, but I will focus in the following paragraphs on the voice and the oral speech as forms of absolute friability, retaining the invariable aspects processed by the memory and transformed into images as well as the transient and occasional experiences registered as absence and impossibility. To exemplify, I will quote further some samples regarding the voices of the writers from "Viaţa românească" cenacle: "When Sadoveanu voiced the strong words of a harsh character in a severe circumstance, his voice sounded choked, as a strangled waterfall somewhere." (Sevastos, 2015: 177). Another example about N. Quinezu: "He talked slowly in a Moldavian language full of picturesque, with a whispering and moderate voice, bursting out unexpectedly into laughs that, by contrast, had something diabolical, after a joke or as an anticipation of a humorous word." (117). Or about I.I. Mironescu: "He recited with a cunning naivety, gesticulating like the characters, and moulding his voice in the logic of the dialogue." (168). And finally, the voice of G. Topîrceanu: "He talked in a Wallachian accent, striking in the Moldavia of «hey» and «a bit»"

According to the quoted fragments, the memoirs register different aspects of the voice: some fragments illustrate the accent ${ }^{11}$ or the timbre, other grasp the performance, and other instances characterize it by the means of metaphor and comparison. The memory is able to keep only some subtle features, nuances, and late images of the voice that are even harder to grasp than other elements of the conversation such as gestures, attitudes, behaviour

\footnotetext{
8 "Viaţa româneacă" cenacle meets between 1906 and 1930 (when the revue moves to Bucharest), while the memoirs are published much later: Ionel Teodoreanu's Masa umbrelor is published in 1947, Mihail Sevastos's Amintiri de la "Viața româneacă" in 1956 (and rewritten in 1966), and Demostene Botez's Memorii in 1970.

${ }^{9}$ All translations from Romanian into English are completed by the author of this paper.

${ }^{10}$ For a direct auditory experience I recommend some samples from the archive of Radio România Cultural: Sadoveanu's voice on https://www.youtube.com/watch?v=Dwko QNEU2E, and Al. O. Teodoreanu's voice on https://www.youtube.com/watch?v=RngPq Rncal4.

${ }^{11}$ Several writers of "Viaţa românească" speak with a Moldavian accent. The fact is worth to be noticed as Viața românească develops a cultural paradigm specific to the region generating spatial representations and cultural institutions. The fact is also noticeable in the choice of orthography in the literary works that preserves several regional elements.
} 
etc. becoming disparate fragments in the writers' portraits. Nevertheless, the absence is compensated in the memoirs by the reflection on the phenomena of loss configuring an imagery of evanescence: there are several passages that point to such momentary experiences, results of the presence of the speaker, but also of the public, implying a mutual and lively participation. Ionel Teodoreanu writes down the impression Stere makes on his audience: "He spoke slowly and ruggedly, as the sculpture of Rodin, giving the same impression of hirsute condensation, constructed hallucination, and built-in storm. The silence of his literature does not define him as the vibration of his voice. Whoever didn't hear him, missed him out: that one, the volcano resembling Rodin, the mythological Stere." (Teodoreanu, 1947: 27). It is an interesting choice of words in Teodoreanu's portrayal of Constantin Stere: the use of the metaphor "the sculpture of Rodin" to describe the writer's voice as a way to grasp something that is out of reach, the priority of the voice over the written work, and the use of the word "mythological" that inverses the relation between oral and written. The mythology of the writer, developed by the Romantic $19^{\text {th }}$ century, is linked to the professionalization of writing and the image of the man of genius, solitary and isolated in the silence of his room, making of writing his vocation ${ }^{12}$. For Teodoreanu, the image of Stere as performer in front of an audience has clearly a deeper and complex relation with the writer Stere than his literature does: the verbalization, the dynamic of the discourse, the very presence of the writer, and his voice implying "vibration", hence an emotional mark, become the features of the writer, whereas his literature is seen as "silence", therefore in a state of numbness. Demostene Botez realizes a similar portrayal when talking about Ibrăileanu, only, in this case, is not so much the performance that counts, but the discourse itself:

"If I don't know how, secretly, so he didn't know, a stenograph or a secret magneto phone registered everything he said every day, from 1906 to 1930, while he was always present at the office, it would have gathered a monumental work of great interest and originality that would have exceeded his written work in which, due to a sort of shyness, he didn't put in all his thoughts." (Botez 1970: 360).

Botez employs such words as "monumental", and "original" in order to define the oral discourse, attributes that usually characterized the written work. In addition, the writing is seen as a process of selection due to an

\footnotetext{
${ }^{12}$ In Romania, the mythology of the man of genius must be linked to the idea of national community. While the first Romantic writers, the 1848 generation, are voices of the nation, the Junimist writers distance themselves from the community, representing the writing as a solitary vocation. ( $c f$. Mironescu, 2016).
} 
emotional impulse ("shyness") and not rational, in which case it diminishes the work of the writer, the final product - the written work - being the result of the personal restrictions. The investigation of the conversation as a phenomenon of loss opens up the discussion on such issues as literary canon, or cultural memory. Jan Assmann (2015) uses these terms to describe "connective structures" between the present and the past, referring to institutionalized and artificial ways of preserving society's memory. The conversation consumes itself in the space of the cenacle; the performance, the passion, the participation are only possible as presence, wherefrom their extreme fragility, soliciting only the short-term memory of the participants. Nevertheless, the spoken word is perceived as part of the writer's work, and sometimes even more valuable than the written one. In this case, I believe the "loss" is thought to belong not only to the affective community that is the cenacle, but to the history of literature as well.

The next issue to be approached is the forms of the conversation, the ideas the cenacles has about the conversation, and the self-image it configures. At the cenacle, the conversation takes the form of the shared discussion (as a contrast to the salons, where there is a delimitation between the actor of conversation and the public), following the pattern of a democratic society (Glinoer, Laisney, 2013). Each member has the right to intervene anytime in the conversation, each opinion is taken into consideration, and the aim is to debate, and therefore to enrich, every idea that comes along. This democracy of the word is not only a common feature of the cenacle, but a conscious adoption of a conversational model. Viața românească is a group of intellectuals that hold important positions in the social hierarchy: some of them are high school teachers, professors, doctors, or even politicians, but at the same time the cenacle is opened to young writers, former students, debutants. Every member of the cenacle, regardless their social statute, contributes to the "maintenance" of the magazine ${ }^{13}$, and the leaders of the group refuse the sophisticated titles (Ibrăileanu and Topîrceanu are editorial secretaries just as Mihail Sevastos, a marginal writer). This democratic image becomes visible even in the arrangement of the cenacle's space: a long table in the middle of the room, surrounded by chairs, permitting the members to face each other all the time, and to occupy equal positions (the top of the table is occupied by Sevastos while Ibrăileanu seats on his left, at the long side of the table). The intellectuals of Viata românească promote a democratic ideology that advocates the equality

\footnotetext{
${ }^{13}$ See Demostene Botez's testimony: “Viața românească revue was literarily the revue of a group of intellectuals who published it by doing absolutely all the editing and administrative tasks required. Professors and teachers, often men of a certain age, considered that is the same thing to write today a short story for the magazine, or to keep the evidence of the subscribers, to stick the addresses, and to do the expedition tomorrow." (Botez, 1966).
} 
between social classes. In my opinion, though the intimate practices of the cenacle such as the conversation escape the ideological-based interpretation as they depend on collaborative and affective relations, the "poporanism" 14 promoted by the cenacle shapes a collective attitude (Ibrăileanu himself defines the concept of "poporanism" as behaviour in writing) that influences the forms of the conversation. Therefore, Viața românească group avoids strict regulations, cultivating a form of casual intimacy that escapes the emphasis, and a form of participation that denies hierarchies. However, the conversation is not at all chaotic as it might seem, the democracy of the word has its restrictions and limitations, and even its freedom is often thoroughly constructed according to the image of some personalities of the cenacle. All the memoires of the cenacle testify about the powerful attraction Ibrăileanu has among the members of the cenacle, and his personality, but also his ideas, are invested as a model for the conversation. One of the features of this conversational model is the anti-rhetoric: "Nobody dared to be eloquent next to Ibrăileanu who could express anything with all the nuances, in a manner of speaking that is the equivalency of the urgent telegram" (Teodoreanu, 1947: 34). The cenacle itself, as Glinoer and Laisney demonstrate, seeks to transform the conversation of the salon that focusses rather on the execution than on the content and makes use of eloquence, into a spontaneous discussion lacking rhetorical performance. In the case of "Viața românească" group, the anti-rhetoric has a different causality, namely the philosophy of style developed by G. Ibrăileanu.

In writing, Ibrăileanu seems to preserve the traces of the speech, and the dynamics of the discourse as marks of the intelligence caught in the act, although the fact is not at all so sympathetically interpreted by his contemporaries. The lack of style in Ibrăileanu's writings is often the ground for the attack coming from his opponents: Nicolae Iorga, Ovid Densusianu, Mihail Dragomirescu Simion Mehendiți use it in their debates with "Viața românească" revue. The "roughness" of the literary critique's style does not even escape the observations of his circle of friends: Sevastos writes down in his memoirs that Stere characterizes it as an unnatural manner to start the sentence with "because" (Sevastos, 2015), Izabela Sadoveanu (1930) qualifies it as "rugged", but in the same time appreciates the absence of the rhetorical effects and the fact that "style is incorporated in the idea", Tudor Vianu (1927) thinks the style adapts to the necessities of thinking, Mihai Carp (1936) speaks about a "telegraphic" style that is consistent to the

\footnotetext{
14 "Poporanism" is the ideology promoted by "Viața românească" magazine and theorized by G. Ibrăileanu. On the one hand, it has a social and political meaning by promoting the need to elevate the Romanian peasant through political rights and economic power. On the other hand, "poporanism" has a cultural significance by arguing the importance of tradition (oral as well as written) for the consolidation of the Romanian literature.
} 
concentration of the ideas. In a letter addressed to Ioan Al. Brătescu-Voinești, Ibrăileanu himself admits the deficiency of style in his writing, result of his lack of ambition, and cynical ignorance of the public:

"Careless, almost cynical as I am, I quickly write what I have to write and I never torture myself to stylize, to come to the best form I am capable of. (...) I go in public without my tie, because I don't think to the public's reaction. (...) I have seen one of Taine's facsimile. There was a struggle to make the sentence beautiful, corrections, and erasures with no connection to the idea, but only to the expression this thing is, of course, explicable by the (artistic) love for beautifulness, but also to the ambition - noble indeed - to make a great impression”. (Ibrăileanu, 1978: 310-311).

For Ibrăileanu, writing has to incorporate the experience of life, therefore the impression of blanks and pauses, the tone of familiarity and spontaneity, the incoherence and roughness of his style that almost seek to imitate the process of thinking, or even the speech that, as suggested by Botez (1970), exceeds the written. This compatibility between the form and the content is only apparently the result of the spontaneity. Ibrăileanu permanently works on his articles and reviews, and sometimes he intervenes when the text is already printed and ready for publication by adding and eliminating sentences, but the modifications occur only to clarify or to enrich the idea of the text, and never to embellish the style. Therefore, the "rugged" style or the lack of style is not at all mere negligence as Ibrăileanu suggests in the quoted letter, but a conscious choice of form. The beautiful expression has a double meaning for Ibrăileanu: it is "artistic love for beautifulness" or in other words lack of finality and gratuitousness of the artistic act, but also a manner to perform and make impression on the audience, meaning its goal is to seduce. On the contrary, the anti-rhetoric, ignoring the presence of the public, is the manifestation of the writer's attitude and thinking, or, in Ibrăileanu's terms, the writer's "tendency". Antonio Patraș (2007) considers that the so-called lack of style is connected to the theory of personality developed by Ibrăileanu: understanding the literary text as a discourse expressing the writer's conception on the world (in which case, literature is always realistic), Ibrăileanu dismisses the talent as a form of falsity that embellishes the sterility of the ideas, whereas the deficiency in style is the result of a strong and original personality with a complex conception on life, and who concentrates rather on the content than on the execution. This interpretation of style brings a new perspective on the forms of the conversation the cenacle embraces: the anti-rhetoric stated by Ibrăileanu's spontaneity represents a form of individuation as each writer who speaks is encouraged to express his personality instead to make an impression on the 
audience. It is relevant that Ionel Teodoreanu describes the discussions of the cenacle as a series of conversational styles that function as portraits of the writers:

"In the real discussions, don Mihai remained (eloquently) silent, Ralea was subtle (and sometimes lawyer); Ibrăileanu equally subtle (but always arbitrator); Topîrceanu was logical and sometimes unexpected, surprising; Stere, imposing, impetuous, and soliloquizing, immune to the dialogue; doctor Cazacu, vituperative, accusatory, with bulging eyes and strong fists; Mironescu, concise; Costică Botez, vertiginous and expressive; Iancu Botez, violent and authoritarian[...];Demostene Botez, gentle; Păstorel, caustic, and Ionel, metaphorical..." (Teodoreanu, 1947: 34-35).

Teodoreanu's description depicts a polyphonic configuration of voices, tonalities, gestures, and behaviours, some of them relaxed or tensioned, argumentative or detached, communicative or reserved, all of them occurring spontaneously beyond any rules of conversation as manifestations of the writers' personality.

Another form of the conversation is the delicacy, seen as a feminine manner of expression. Viața românească is mostly a group of men, the presence of the female writers is rarely registered in the common space (Otilia Cazimir remembers her participation at the cenacle as a sporadic event), and the memoirs of the group does not recall any feminine presence (Demostene Botez even laments about the women's avoidance of the cenacle). However, the masculine exclusivity does not shape a virile ambiance that would allow obscene jokes and innuendoes, the anecdotes remaining between the limits of complaisance. The model for this feminine manner is again Ibrăileanu, the leader of the group:

"Mister Ibrăileanu's delicacy seems to me as an exotic phenomenon. [...] Rarely there are men who when alone, among themselves, do not hustle with confidences and embarrassingly juicy anecdotes. Rarely there are men who do not have a few expressions in their private vocabulary similar to swear words or vulgarism [...]. But mister Ibrăileanu is delicate, without effort and hypocrisy. Intelligent, lucid, intuitive with the human mechanism, but still gentle". (Teodoreanu, 1947: 37).

The choice of the word "delicacy" in order to characterize the leader of Viața românească group is justifiable when looking to Ibrăileanu's thinking. In Privind viața/Regarding Life, Ibrăileanu himself defines delicacy as a qualité maîtresse that encompasses all the noble virtues, possible only as 
unity, the absence of one part affecting the whole: "The delicacy is the supreme and most rare quality of the human soul. It implies all the others: intelligence, kindness, altruism, generosity, discretion, nobility etc. A man lacking a single quality of the soul has the delicacy incomplete. Then it has voids and shadows" (Ibrăileanu, 2010: 707). The delicacy functions, in Ibrăileanu's conception, as a social and ethical conduit in life, and becomes a matter of dosage according to the circumstances and the social interactions (cf. Patraş, 2007): "In society never stand against any error, so you don't commit unknowingly an indelicacy." (Ibrăileanu, 2010: 703). In his lectures held at Collège de France, entitled Comment Vivre Ensemble (2002), Roland Barthes defines delicacy as the most suitable conduit in a community. For Barthes, the living-together is the result of a physics and ethics of the distance that allow to preserve the solitude inside the community without eliminating the issue of affection, in which case delicacy becomes a form of "distance and respect" that escapes the manipulation and the imposition of the self-image on the others (Barthes, 2002: 179-180). In the portrayal made by Teodoreanu, the delicacy is seen as a feminine quality that is able to influence the men around and to elevate them from the biological state ("a sensation of escape from the heavy clay into a vivid light"), and again the idea is borrowed from Ibrăileanu. The delicacy is seen by the literary critique as an organic form of intelligence specific to women that makes opposition to the intellectualism, sensed as an excess and simulacrum of intelligence. In literature, the superiority of the female writers consists in the "delicate attitude towards the subject" (Ibrăileanu, 2010: 624), rather a moral than aesthetical quality which refers to the compassion for the fragile being, and to the capacity of understanding the human soul (or the "human mechanism" in Teodoreanu's words). At the cenacle, Ibrăileanu assimilates this feminine attitude and while the deficiency in style calls the exhibition of the inner personality (that is always a masculine affair), the delicacy demands moderation and discretion as forms of social interaction.

The last issue to be analysed regarding the forms of the conversation is the admiration for certain writers of the cenacle. As stated before in this paper, the idea of the democratic community where each member is free to intervene and express his opinion shapes the conversation of the cenacle. However, the literary admiration replaces the lack of hierachies: at the cenacle, there are dominant figures that direct and animate the atmosphere, or even monopolize the discussion. All the memoirs testify about the attraction for Ibrăileanu's speech that modulates and directs the discussion, but he is not the only actor of the conversation. Demostene Botez registers the admiration for Mihail Sadoveanu that changes the flow of the discussion: 
"There was in him, in his being, the amazing power of prestige. When he entered, in Iași, at the office of that magazine, even Ibrăileanu's facial expression changed. You could read on it both shyness and admiration. All of us, young and old, would stand up and from that moment the flow of the discussion changed in tonality, denoting more cautiousness in mind and speech" (Botez 1961: 11).

Sadoveanu's entrance at the editorial office triggers a series of reactions from the members of the cenacle: they change their position by standing up, clearly a mark of respect and admiration, and the leader himself exposes his admiration through non-verbal signs as facial expression. In addition to this, the conversation changes its course, its "tonality", and the members become more cautious with the words they use. Therefore, the admiration functions as a hierarchical mark that shapes the rhythm of the conversation and limits the spontaneous speech. Sometimes the discussion becomes monologue, and there are voices inside the cenacle that become actors of the conversation, and transform the democratic atmosphere into a theatrical space redistributing the roles between the speaker and the audience. Ionel Teodoreanu remembers one of Stere's visits at the editorial office of Insemnări literare, housed by Demostene Botez's domicile:

"He retold Siberian memories, evoking in a hallucinatory manner a multitude of people, and not in the talkative way of the Moldavian storytellers, but absolutely different, resembling the symphonic winds that awakes the organs of the great cathedrals. I was listening openmouthed, crushed with admiration." (Tedoreanu, 1947: 73-74).

This is Teodoreanu's first encounter with C. Stere, and the writer's performance in the cenacle induces a sort of a catatonic state to the young debutant. The admiration has as a consequence the abandonment of the writing and the isolation from the cenacle for a period of time, followed by a new phase in the creativity process: "The Stere storm, after crushing me by confronting me with another dimension of creativity - the fluvial one fertilized my will to create by fighting. I started writing in secret the Medeleni." (74). The admiration is directly related to the writer's vocation, marking his sterile and creative phases, and influencing the future work of art. At the cenacle, the forms of the conversation are rather expressed as a set of social conduits meant to shape the intimate discussion than as discursive manners to deliver a speech: the anti-rhetoric as a form of spontaneity of the writer's personality, the delicacy as a code of social interaction, and the admiration as literary hierarchy imply an affective and ethical vocabulary regarding the forms. 
The democracy of the conversation, the lack of rules and social codes, and the rejection of the rhetoric shape not only the forms but also the content of the conversation. At the cenacle, the writers talk about a wide variety of subjects, from literature, philosophy, and politics, to anecdotes, memories, confidences, daily news, or social events. The writers sense the conversation as a way to disconnect from the everyday problems; at the cenacle, they come undoubtedly to enjoy themselves, but the reason for their cohabitation lies in the desire to share ideas, and to discuss literature in a suitable space, dedicated to intellectual life. For Ionel Teodoreanu, the ideal image of the cenacle is the intimate discussion on essential problems that elevates the human being above the routine, favouring the appearance of a society of intellectual friends, isolated from the rest of the world, and whose main goal is literature: "The discussion started naturally from the worries of each of us, or the daily public events, but quickly they were abandoned elevating towards books, ideas, and ideals (the small talk became suspicious, but there was no small talk there). The tone was intimate and passionate." (34). Hence, the "small talk is suspicious" which means the gratuitous discussion is felt as wastage, the cenacle remaining the place of elevate conversation that escapes the loquacity of the everyday. On the contrary, Sevastos seems to remember a different direction of the conversation that begins with the high-tone discussion, and moves to the ordinary talk, the transition being usually solicited by Ibrăileanu who had a taste for gossip: "[Ibrăileanu] would cry out, impatiently running one hand through his dishevelled hair: "Give me a break from literature. Better tell me a simple fact that directly reflects life»" (Sevastos, 2015: 276). The members of the cenacle sometimes perceive the specialized conversation as an excess that fossilizes the dynamic of the group and isolates the writer from life. On this account, the conversation of the cenacle is always in connection with the daily events; it is contaminated by anecdotes and laughter, and the work is often quitted for the mere pleasure of the conversation. Which image presented in the memoirs is closer to reality? Is the cenacle an elitist space where literature is the main subject or the place of anecdotes and delight? On the one hand, the cenacle meets to discuss the future of literature, and it is, indeed, the "profitable" conversation, as Glinoer and Laisney show, that explains its existence, differentiating the cenacle from other forms of sociability such as the salon or the literary café. On the other hand, the taste for small talk always interferes with the high-end discussion; the writers of the cenacle enjoy talking about incidental events, about their daily routine, or the public events, making jokes and laughing together.

Several discussions of the cenacle have as a starting point the articles received for the publication in the magazine, having the practical goal to smooth the style, to clarify the arguments, or to eliminate the irrelevant paragraphs. Sevastos writes about the discussions around the problems of 
style that are debated several hours in the cenacle, involving as actors the socalled "stylists" of the magazine, namely Ibrăileanu, Mihai Carp, Sadoveanu, Topîrceanu, Ion Botez, Constantin Botez, and Octav Botez. The ideas discussed are the origin of a collective stylistic canon which Sevastos carefully delineates in his memoirs:

\begin{abstract}
"The stylists of Viața românească never used two inter-connected subjunctives except in the dialogue, and mainly when the redundant expression was articulated by a peasant [...]. It was forbidden to write a sentence using multiple genitives. There were allowed two or three at most and not of same gender and number [...]" (Sevastos, 2015: 67).
\end{abstract}

Therefore, the members of the cenacle make use of the shared conversation in order to define a collective idiom: they come to imitate and influence reciprocally, they educate their personal style according to the rules they debate together, and the collective work - Viața românească magazine benefits from this collective effort. The cenacle also works as the laboratory for the future writings as the ideas are first exposed, verified, and filtered by the collective opinion before being transposed into writing and being published. Demostene Botez remarks in his memoirs that Ibrăileanu's articles are preceded by the presentation and the probation of the ideas in front of the group: "It appears to me now that those discussions were for him a lively laboratory for his future literary reviews. Testing his ideas through the opinions of the friends was a method to strengthen his beliefs and to put them in writing." (Botez, 1970: 360).

In the cenacle, the "profitable" discussion meets the agreeable conversation. Viața românească memoirs seem to privilege the image of the cenacle as societé vivante that values the free time and the small talk against the elitist image of the circle of intellectuals. The preference for this imaginary has a twofold explanation. In first place, the representation of the cenacle as a joyful society of writers has a precedent in the cenacle's imaginary, namely the Junimea group. It is a fact that the first Romanian cenacle valued the good time, and even had a famous saying stating that "at Junimea first come the anecdote": the writers used to organize parties, anniversaries, feasts, pornographic readings, pillow fights etc. The model is not fully imitated by Viața românească cenacle that, as shown before, relates to a form of delicacy and femininity instituted by Ibrăileanu's personality, but the image of the convivial society is clearly engaged by the "progessionist" writers of Viața românească. In the second place, the agreeable conversation contributes directly to the configuration of the collective memory: the anecdotes, the incidental events, the confidences constitute a specific identity of the group that differentiates it from other communities; they become 
symbols of the living-together that compensates the absence of the community.

Viața românească cenacle dismisses the formal rituals of the classical conversation, and the eloquence, as I demonstrated, becomes suspicious, favouring the discussion with no rule, irregular, and chaotic. The meetings have no fixed timetable, the working hours and the free time always interfere, and the agreeable conversation often dominates the atmosphere. Glinoer and Laisney show that the anecdote functions inside the cenacle as a "collective disinhibition" as it is accompanied by laughter that has a cathartic effect upon the group. Daniel Sibony considers that collective laughter has a symbolical and social meaning that transcends the individual amusement. On the symbolical level, the laughter manifests as a collective force that transforms the personal anxieties, the vanities, and the deficiencies into strong points of the group: "Laughter demands more in a symbolical sense; it means to be strong; strong enough to appear weak" (Sibony, 2010: 112). The laughter implies a risk taken in front of the others: on the one hand, it is the reinvestment of the incapacity as intensified force, and, on the other hand, it is the collective capacity to react to the stimuli coming from each participant. At the social level, the laughter manifests as social vanity as it suspends the personal narcissism, and celebrates the existence of the group itself beyond any reason. From this perspective, the laughter has a subversive as well as a conservative role: on the one hand, it makes use of the weaknesses in order to fracture the personal vanities, but on the other hand, it becomes force by celebrating the living-together without demanding external causes.

Further on, I will analyse some examples of agreeable conversation that is meant to produce laughter among the writers of the cenacle. Most of the stories presented at Viața românească refer to personal adventures, introduced with such phrases as "wait to see what happened to me" or with temporal adverbs such as "once" or "one day". In order to seduce the public and produce the laughter, the anecdotes require that the discourse were efficient (accommodation with the expectations of the others, anticipation of the reactions), privileging the performance of the speech. For example, Sevastos reproduces an anecdote narrated at the cenacle by Stere, focussing on the storyteller's interpretation in front of the audience: "and Stere demonstrated how he had hidden behind the dancers and had squinted with the tail of the eye at the menacing witch whom he imitated for the laughter of the listeners." (Sevastos, 2015: 88). The cenacle also takes pleasure from the gossip and the scandals coming from the high-class society: "Let me tell you what kind of roguery pulled once don Ghiță, the former police marshal, whom you all know - political head whatever..., a smart and pleasant man, all the same, but a big merrymaker." (88). The intellectual atmosphere of the cenacle is not immune to the sensational stories of the high life, but they call 
an intimate and shared pleasure with friends who have a similar intellectual background, and not a direct participation. The collective laughter also indicates the possibility to make jokes on the others. In spite of the fact that the friendly derision isolates the subject of the joke, it also function as a symbol of validation on the part of the group as the joke is only possible among close friends, in the proximity of the affront but remaining between the limits of the complaisance. At Viața românească cenacle the jokes refer to the oddities, habits, phobias, aiming the weaknesses of the other. For example, Ibrăileanu is teased on the account of his exaggerated fear of germs and the prophylactic measures he takes with no reason, and Topîrceanu is targeted on the account of his love affairs or his idleness in writing.

The democracy of the word articulates a new conception about the free time. In "the genealogy of the social usage of time" (Corbin, 1995: 16), the spent time at the cenacle is perceived by its members as "time for oneself" (the French defines it best with the term loisir), the private space and the collective space becoming unseparated. The writers come to the cenacle "to do their job", to bring manuscripts and articles, to read and make corrections, or to work at the magazine, but also they come here to spend their free time with the people of same background, to profit from the conversation and to relax by a particular form of amusement of the group. Roland Barthes shows that the communities of vivre ensemble type lack the militant goal that usually marks other social groups, their aim (Télos) being the pure pleasure for sociability without further objectives (Barthes, 2002: 83-84). The majority of the writers from Viața românească have other professions such as lawyer, professor, banker, teacher, professions that they practice along with the writing. The working hours are divided between the job and the writing, therefore the time shared with the friends at the cenacle is an agreeable manner of time usage. From this perspective, the free time is time shared with: with other writers, with people that have the same interests and the same ideals.

The analysis of the conversation that takes place in the cenacle opens up new perspectives in the field of literary studies. Valuing the intimacy over ideology, and the process over the finality of the literature, the present investigation questions such concepts as cultural memory, literary canon, writing, discursive forms, or literary community in order to address the issue of small communities that imply fragility and loss, ethical forms of discourse such as spontaneity, delicacy, and admiration, or the pleasure for being together. The research on the conversation of Viața românească cenacle allows extending the analysis beyond the ideology of "poporanism" promoted by the group, a strong concept that is engaged in the debates of some searing issues of Romanian culture (national specificity, local 
tradition), to the functionality of a community of writers, the mechanisms and the collective education they employ in order to live together.

\section{References:}

Assmann, J. (2013). Memoria culturală. Scriere, amintire și identitate în marile culture anticel Cultural memory. Writing, remembrance, and identity in the early civilizations. Iași: Editura Universității „Alexandru Ioan Cuza”.

Barthes, R. (2002). Comment Vivre Ensemble. Simulations romanesques de quelques espaces quotidiens/ How to Live Together: Novelistic Simulations of Some Everyday Spaces. Seuil: IMEC.

Blaise, M., Triaire, S., Vaillant, A., eds. (2009). L'histoire littéraire des écrivains. Paroles vives./ The Literary History of the Writers. Lively Words. Montpellier: Presses universitaires de la Méditerranée. Disponibil pe : https://books.openedition.org/pulm/829?format=toc. https://doi.org/10.4000/books.pulm.829.

Botez, D. (1961). Mărturisiri/ Testimony. În Viaţa românească. November, nr.11, pp. 64-66.

Botez, D. (1966). Mihai Carp. În Viața românească, March, nr.3, pp. 163-166.

Botez, D. (1970). Memorii/ Memoirs. București: Minerva.

Carp, M. (1936). Stilul lui Ibrăileanu/ Ibrăileanu's Style. În Însemnări ieșene. AprilMay, nr. 9, pp. 403-407.

Corbin, A. (1995). L'Avénement des loisirs, 1850 - 1960/ The Birth of the free time, 1850 - 1960. Paris: Aubier.

Diaz, J.-L. (2003): Quelle histoire littéraire?/ What Literary History?. Revue d'histoire littéraire de la France, 3 (vol. 103), from https://www.cairn.info/revue-d-histoire-litteraire-de-la-france-2003-3-page515.htm. https://doi.org/10.3917/rhlf.033.0515

Fumaroli, M. (1994): Trois institutions littéraires/ Three Literary Institutions. Paris: Gallimard.

Glinoer, A., Laisney, V. (2013). L’âge de cénacle. Confraternités littéraires et artistiques au XIXe siècle/ The Time of the Cenacle. Literary and Artistic Confraternities in the 19th Century. Paris: Fayard.

Ibrăileanu, G. (1978). Opere/ Works, vol. 6 (Al. Piru, R. Rotaru, Eds.). București: Minerva.

Ibrăileanu, G. (2010). Scrieri alese/ Selected Writtings (A. Patraș, R. Patraș, Eds.). Iași: Editura Universității „Alexandru Ioan Cuza”.

Laisney, V. (2003). Choses dites: petite histoire littéraire de la parole au XIXe siècle/ Spoken Words: Small Literary History on the Speech in $19^{\text {th }}$ Century. In Revue d'Histoire Littéraire de la France, 3 (vol. 103), pp. 643-653. From https://www.cairn.info/revue-d-histoire-litteraire-de-la-france-2003-3-page643.htm\#. https://doi.org/10.3917/rhlf.033.0643

Leonte, L. (1998). Continuitate și înnoire (,Viața românească” în perioada interbelică/ Continuity and innovation ("Viața româneacă" in the interwar period). In Scriitori, cărți reviste/ Writers, books, magazines. Iași: Cronica. 
Mironescu, D. (2016). Un secol al memoriei. Literatură și conștiință comunitară în epoca romantică/A Century of Memory. Literature and Collective Conscience in Romanticism. Iași: Editura Unversității „Alexandru Ioan Cuza”.

Ornea, Z. (1972). Poporanismul/ The Poporanism. București: Minerva.

Patraș, A. (2007). Ibrăileanu. Către o teorie a personalității/ Ibrăileanu. A Theory on the Personality. București: Cartea Românească.

Sadoveanu, I. (1930). Studii literare/ Literary Studies. În Adevărul literar și artistic. April 6, nr. 487, p. 4.

Sevastos, M. (2015). Amintiri de la ,Viața românească”/Memories from "Viața românească” circle. Iași: Polirom.

Sibony, D. (2010): Les Sens du rire et de l'humour/ The Significance of Laughter and Humour. Odile Jacob.

Teodoreanu, I. (1947). Masa umbrelor/ The Table of Shadows. București: Forum.

Tudurachi, L (2019): Grup sburător. Scrisul și trăitul împreună în cenaclul lui E. Lovinescul Sburătorul Group. The Writing and the Living in E. Lovinescu's Cenacle. Timișoara: Editura Universității de Vest.

Vianu, T. (1927). Scriitori români şi străini/ Romanian and Foreigner Writers. În Gândirea. May 5, nr. 5, pp. 190-191. 